\title{
PENGARUH PEMBERIAN HORMON 17ß-ESTRADIOL TERHADAP PERKEMBANGAN GONAD SIPUT GONGGONG Laevistrombus turturella
}

\author{
EFFECT OF 17ß-ESTRADIOL HORMONE ADMINISTRATION ON \\ THE DOG CONCH'S Laevistrombus turturella GONAD DEVELOPMENT
}

\author{
Muzahar ${ }^{1}$, Muhammad Zairin Jr. ${ }^{2 *}$, Fredinan Yulianda ${ }^{3}$, \\ Muhammad Agus Suprayudi ${ }^{2}$, Alimuddin ${ }^{2}$ dan Irzal Effendi ${ }^{2}$ \\ ${ }^{1}$ Program Studi Budidaya Perairan, FIKP-UMRAH, Tanjungpinang, 29124, Indonesia \\ ${ }^{2}$ Departemen Budidaya Perairan, FPIK-IPB, Bogor, 16680, Indonesia \\ ${ }^{3}$ Departemen Manajemen Sumberdaya Perairan, FPIK-IPB, Bogor, 16680, Indonesia \\ *E-mail: zairinmz@live.com
}

\begin{abstract}
Dog conch Laevistrombus turturella is captured intensively, therefore, their population is decline. The dog conch culture is needed to maintain their population. The technology towards conch reproduction is still not developed yet in Indonesia. The 17ß-estradiol hormone in conch and some mollusks has been stated by some researcher yet its main role in conch reproduction process has not widely known. The study about the addition of $17 \beta$-estradiol hormone in accelerating gonad development has never been reported. The aim of this study was to evaluate the impact of the addition of 17 $\beta$-estradiol against dog conch's gonad development. This study used three treatments for three groups of dog conch those were without injection (P1), injection by $30 \mu \mathrm{L}$ of corn oil mixed with absolute ethanol $(P 2)$, and $30 \mu L$ of $17 \beta$-estradiol stock solution (P3). After injection, the dog conch was reared in pens culture in their natural habitat for 30 days. This study showed that the injection of a 17ß-estradiol solution (P3) stimulated the dog conch's gonad development as evidenced by greater oocyte mean diameter than another treatment. The mean of gonadal weight and GSI on P3 treatment was also higher than treatments $P 1$ and P2. SDS-PAGE analysis showed that dog conch's hemolymph has several kinds of proteins with varying molecular weights. Proteins with a molecular weight of 54-55 $k D a$ are predicted as dog conch's vitellogenin.
\end{abstract}

Keywords: $17 \beta$-estradiol hormone, dog conch, gonad development, Laevistrombus turturella

\begin{abstract}
ABSTRAK
Siput gonggong Laevistrombus turturella semakin intensif ditangkap sehingga populasinya di alam menurun. Upaya budidaya gonggong diperlukan untuk menjaga populasinya. Teknologi reproduksi siput belum banyak dikembangkan di Indonesia. Keberadaan $17 \beta$-estradiol pada siput dan moluska lain telah dinyatakan oleh beberapa peneliti, namun perannya dalam proses reproduksi siput belum banyak diketahui. Penelitian tentang pemberian 17ß-estradiol untuk memacu perkembangan gonad gonggong belum pernah dilaporkan. Penelitian ini bertujuan mengaji pengaruh pemberian 17ßestradiol terhadap perkembangan gonad gonggong. Ada tiga perlakuan yang diberikan pada tiga kelompok gonggong, yaitu masing-masing tanpa suntikan (P1), suntikan $30 \mu \mathrm{L} / \mathrm{ekor}$ larutan minyak jagung dan etanol absolut (P2), serta suntikan $30 \mu \mathrm{L} / \mathrm{ekor}$ larutan 17 $\beta$-estradiol (P3). Pascasuntikan, gonggong dipelihara dalam pensculture di habitat alaminya selama 30 hari. Hasil penelitian menunjukkan bahwa perlakuan suntikan larutan 17 $\beta$-estradiol (P3) menstimulasi perkembangan gonad gonggong yang dibuktikan dengan nilai rata-rata ukuran diameter oosit yang lebih besar daripada perlakuan lain. Nilai rata-rata bobot gonad dan GSI perlakuan P3 juga lebih besar dibanding perlakuan P1 dan P2. Analisis SDS-PAGE menunjukkan hemolimfa gonggong memiliki beberapa jenis protein dengan berat molekul bervariasi. Protein dengan berat molekul 54-55 kDa diprediksi sebagai vitelogenin gonggong.
\end{abstract}

Kata kunci: gonggong, hormon 17ß-estradiol, Laevistrombus turturella, perkembangan gonad 


\section{PENDAHULUAN}

Gonggong Laevistrombus turturella merupakan siput laut yang sangat terkenal di Provinsi Kepulauan Riau (Kepri) sebagai seafood dengan rasa daging yang enak. Gonggong mengandung protein hewani yang tinggi, yaitu $38,91 \%$ pada bagian otot, dan $46,65 \%$ pada bagian jeroan, namun kadar lemak dan kolesterolnya rendah, masingmasing 0,78-2,26 mg/100 g dan 9,89-24,95 $\mathrm{mg} / 100 \mathrm{~g}$ (Muzahar dan Viruly, 2014). Gonggong memiliki nilai ekonomis tinggi dan merupakan sumber mata pencarian bagi penduduk yang bertempat tinggal di sepanjang pantai Pulau Bintan, Pengujan dan Dompak. Gonggong merupakan ikon Kota Tanjungpinang-Provinsi Kepri. Gonggong semakin intensif ditangkap sehingga populasinya di alam cenderung menurun ditandai dengan ukuran tangkap semakin kecil dan jumlah yang diperoleh semakin sedikit (Muzahar dan Hakim, 2018). Populasi gonggong dapat dilestarikan dengan cara dibudidayakan, namun teknologi rekayasa reproduksi siput gonggong belum berkembang. Informasi fisiologi reproduksi dan pematangan gonad gonggong pun masih sangat terbatas. Namun, informasi mengenai waktu dan laju kematangan gonad dapat ditetapkan berdasarkan pengamatan makroskopis warna gonad dan pengamatan mikroskopis jaringan gonad matang dengan mikroskop seperti yang telah dilakukan pada siput Strombus canarium (Cob et al., 2008a). Salah satu cara dalam merangsang kematangan gonad dan reproduksi pada hewan-hewan akuatik adalah dengan induksi hormonal (Tarsim et al., 2007).

Hormon steroid seperti $17 \beta$-estradiol, testosteron dan progesteron merupakan regulator penting pada reproduksi, fisiologi, dan perkembangan dalam berbagai taksa hewan, termasuk moluska (Keay et al., 2006). Hormon tersebut terlibat dalam kontrol reproduksi, pertumbuhan, metabolisme energi, dan sirkulasi darah dan air pada moluska (Pinder et al.,1999), dan terbukti ikut berperan dalam proses pengendalian reproduksi pada golongan siput seperti pada bekicot Achatina fulica (Kruatrachue et al., 1996), kelinci laut Aplysia depilans (Di Prisco et al., 1973), siput laut Thais clavigera (Lu et al., 2001), serta pada golongan kekerangan seperti kerang Sinonovacula constricta (Yan et al., 2011), dan tiram Crassostrea gigas (Matsumoto et al., 1997). Induksi hormonal dengan menggunakan hormon 17 $\beta$-estradiol telah dilaporkan dapat menginduksi kematangan gonad berbagai spesies krustasea dan moluska. Pemberian $17 \beta$-estradiol pada tahap perkembangan gonad induk udang putih Litopenaeus vannamei meningkatkan nilai gonado somatic index (GSI) dan rerata diameter oosit perlakuan relatif lebih tinggi dibandingkan kontrol, masing-masing sebesar 0,453 dan 23,97 $\mu \mathrm{m}$ (Tarsim et al., 2007). Pemberian hormon $17 \beta$-estradiol berhasil menginduksi perkembangan gonad kerang laut Placopecten magellanicus (Wang and Croll, 2004). Penyuntikkan $17 \beta$-estradiol dilaporkan juga secara signifikan meningkatkan diameter oosit dan kandungan vitelin pada gonad betina tiram C. gigas, serta pada kerang Patinopecten yessoensis (Li et al., 1998; Osada et al., 2003). Dari beberapa laporan tersebut, diduga pemberian $17 \beta$-estradiol dapat memicu perkembangan dan kematangan gonad pada moluska. Namun, pemberian hormon 17 $\beta$-estradiol terhadap perkembangan gonad gonggong $L$. turturella belum pernah dilakukan sebelumnya. Penelitian ini bertujuan untuk menganalisis pengaruh pemberian hormon $17 \beta$-estradiol terhadap perkembangan gonad gonggong $L$. turturella sebagai salah-satu usaha pengembangan teknologi rekayasa reproduksi pada biota ini.

\section{METODE PENELITIAN}

\subsection{Waktu dan Tempat Penelitian}

Penelitian ini dilaksanakan pada bulan Mei-Desember 2018 di laut MadongTanjungpinang dan Laboratorium Program 
Studi Budidaya Perairan, Fakultas Ilmu Kelautan dan Perikanan, Universitas Maritim Raja Ali Haji, Tanjungpinang.

\subsection{Rancangan Percobaan}

Ada dua faktor perlakuan dalam penelitian ini, yaitu (1) faktor disuntik dan tidak disuntik, dan (2) faktor disuntik dan tanpa disuntik $17 \beta$-estradiol. Perlakuan yang dilakukan terdiri atas: tanpa suntikan (P1), diberi suntikan $30 \mu \mathrm{L} /$ ekor larutan minyak jagung dan etanol absolut tanpa $17 \beta$-estradiol (P2), dan diberi suntikan $30 \mu \mathrm{L} / \mathrm{ekor}$ larutan stok 17 $\beta$-estradiol (P3). Masing-masing perlakuan dengan tiga kali ulangan. Volume larutan yang disuntikan mengacu pada penelitian Wang and Croll (2004) pada kerang laut Placopecten magellanicus. Gonggong disuntik pada bagian otot kaki. Pasca-suntik, gonggong dipelihara selama 30 hari dalam masing-masing tiga pensculture untuk setiap perlakuan dengan kepadatan 10 ekor/pens. Selama pemeliharaan, gonggong memperoleh makanan hanya dari substrat dasar yang ada di dalam pens. Detail rancangan penelitian ditampilkan pada Tabel 1.

Tabel 1. Rancangan penelitian penyuntikan hormon $17 \beta$-estradiol pada gonggong L. turturella.

\begin{tabular}{lcc}
\hline \multicolumn{1}{c}{ Perlakuan } & $\begin{array}{c}\text { Jumlah } \\
\text { sampel } \\
\text { (ekor) }\end{array}$ & $\begin{array}{c}\text { Rerata } \\
\text { panjang } \\
\text { cangkang } \\
\text { total (mm) }\end{array}$ \\
\hline $\begin{array}{l}\text { Tanpa suntikan } \\
\text { (P1) }\end{array}$ & 30 & $50,89 \pm 1,88$ \\
$\begin{array}{l}\text { Suntikan } \\
\text { 30 } \mu \text { L/ekor larutan } \\
\text { minyak jagung } \\
\text { dan etanol absolut }\end{array}$ & 30 & $51,82 \pm 2,46$ \\
(P2) & & \\
$\begin{array}{l}\text { Suntikan } \\
\text { 30 } \mu \text { L/ekor larutan } \\
\text { stok 17 } \beta \text {-estradiol } \\
\text { (P3) }\end{array}$ & 30 & $51,84 \pm 0,85$ \\
\hline
\end{tabular}

\subsection{Penyiapan Pens Culture}

Sebanyak sembilan buah pens untuk wadah budidaya gonggong dibuat di habitat alaminya di perairan laut MadongTanjungpinang $\quad\left(00^{\circ} 58^{\prime} 55.60^{\prime \prime} \mathrm{N}\right.$ dan $104^{\circ} 27^{\prime} 01.86^{\prime \prime}$ E) masing-masing dengan ukuran $2 \times 1 \times 0,5 \mathrm{~m}^{3}$ dan kedalaman air 0,15 $1,80 \mathrm{~m}$. Tiang pancang pens dibuat dari kayu berdiameter $5-10 \mathrm{~cm}$ dengan tinggi $3 \mathrm{~m}$ dan ditancapkan sedalam 75-100 cm ke dalam sedimen. Bagian dinding dipasang jaring nilon berwarna hijau dengan mesh size 1,0 inci. Tiang pancang dan jaring diberi penguat berupa batang kayu berbentuk-V yang ditancapkan ke dalam sedimen.

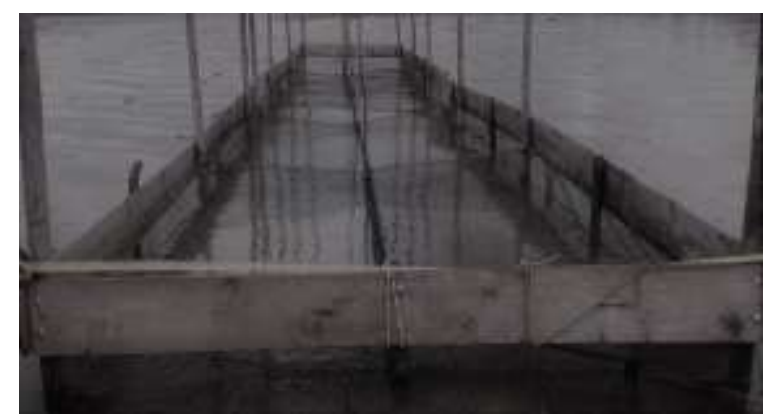

Gambar 1. Pens untuk pemeliharaan gonggong pascasuntikan.

\subsection{Penyiapan Gonggong dan Hormon 17 $\beta$-estradiol \\ Gonggong yang digunakan berada} pada stadia muda. Ukuran gonggong ditampilkan pada Tabel 1. Gonggong diperoleh dari perairan laut Kampong Madong, Kota Tanjungpinang. Gonggong dipilih berdasarkan kriteria Cob et al. (2008b) dan Sanchez et al. (2016), yaitu memiliki gonad yang berwarna kehitaman, dan berada pada fase awal oogenesis yang dicirikan dengan ukuran oosit kecil. Hormon yang digunakan adalah 17 $\beta$-estradiol produksi Argent Laboratories Inc. (Makaty City, Philippines). Larutan stok hormon disiapkan mengikuti metode Wang and Croll (2004) dengan sedikit modifikasi: 0,105 g $17 \beta$-estradiol dilarutkan dalam $5 \mathrm{~mL}$ etanol absolut, kemudian dilarutkan dalam $100 \mathrm{~mL}$ minyak jagung (pengenceran 1:20). Etanol 
berfungsi sebagai pelarut dan minyak jagung berfungsi sebagai zat pembawa hormon agar mudah bergabung dengan cairan tubuh (Wang and Croll, 2004). Konsentrasi akhir larutan stok 17ß-estradiol adalah 1000 $\mu \mathrm{g} / \mathrm{mL}$.

\subsection{Analisis Konsentrasi 17 $\beta$-estradiol Hemolimfa Gonggong}

Hemolimfa gonggong diambil masing-masing dari tiga ekor gonggong dari setiap perlakuan pada hari ke- $0,4,7,10,13$, 16 dan 30 pemeliharaan. Hemolimfa diambil dari bagian kaki gonggong menggunakan jarum suntik berukuran $0,60 \times 32 \mathrm{~mm}$. Hemolimfa yang diperoleh dimasukkan dalam tabung mikro tanpa diberi antikoagulan dan sentrifugasi, kemudian disimpan pada suhu $-20^{\circ} \mathrm{C}$ (modifikasi metode Sathyan et al., 2012).

Analisis konsentrasi hormon estradiol hemolimfa dilakukan dengan metode enzyme-linked immunosorbent assay (ELISA) mengacu pada metode Setiadi et al. (2014) di Laboratorium Hormon, Unit Rehabilitasi Reproduksi (URR) Fakultas Kedokteran Hewan, Institut Pertanian Bogor. Sampel hemolimfa diencerkan secara bertingkat menggunakan aquabidestilata dengan perbandingan mulai dari 1:0 hingga 1:16. Sebanyak $25 \mu \mathrm{L}$ duplo larutan standar dan masing-masing sampel dimasukkan ke dalam setiap sumur terpilih. Setelah itu 200 $\mu \mathrm{L}$ larutan enzim konjugat dimasukkan ke dalam setiap sumur kecuali blanko kemudian ditutup dengan cling film dan dihomogenkan dengan cara digoyangkan secara perlahan selama 10 detik. Setelah itu, dilakukan inkubasi selama 120 menit pada suhu ruang. Setelah diinkubasi, setiap sumur dicuci dengan $400 \mu \mathrm{L}$ washing solution sebanyak 34 kali pencucian, kemudian dihentakhentakan secara perlahan di atas kertas (absorbent paper) untuk mengeluarkan cairan dalam sumur-sumur secara tuntas. Sebanyak $200 \mu \mathrm{L}$ larutan substrat dimasukkan ke dalam setiap sumur kemudian ditutup dengan cling film dan diinkubasi selama 15 menit pada suhu ruang. Reaksi enzimatis dihentikan dengan menambahkan $100 \mu \mathrm{L}$ stop solution $\left(0,5 \mathrm{M} \mathrm{H}_{2} \mathrm{SO}_{4}\right)$ ke dalam setiap sumur. Pembacaan absorbance menggunakan ELISA reader selama 10 menit pada panjang gelombang $450 \pm 10 \mathrm{~nm}$.

\subsection{Analisis Pertumbuhan Bobot Gonad dan GSI Gonggong.}

Pada akhir pemeliharaan dilakukan penimbangan bobot total gonad dan bobot tubuh lunak gonggong untuk memperoleh nilai gonado somatic indeks (GSI). Nilai GSI dihitung dengan formulasi di bawah ini (Marentette and Corkum, 2008):

$G S I=\frac{B g}{B t} x 100$

Keterangan:

$\mathrm{Bg}=$ bobot gonad $(\mathrm{g}) ; \mathrm{Bt}=$ bobot tubuh lunak total $(\mathrm{g})$.

\subsection{Histologi Gonad dan Diameter Oosit}

Gonggong dibedah untuk pemeriksaan histologi. Analisis histologi gonad mengadopsi metode Sanchez et al. (2016) dengan modifikasi. Gonad gonggong difiksasi dalam larutan Bouin selama 24-36 jam dan disimpan dalam etanol $70 \%$ sebelum dibuat preparat histologis. Gonad dipotong untuk dehidrasi dengan alkohol, embedding, parafinisasi, dan clearing dengan kloroform. Hematoksilin dan asam eosin digunakan untuk mewarnai irisan sampel. Preparat dibuat setebal $8 \mu \mathrm{m}$ dan diamati menggunakan mikroskop untuk mengamati tingkat kematangan gonad gonggong. Ukuran diameter oosit dikuantifikasi pada tahapan oogenesis dengan mengukur 100 butir oosit dari tiga individu dari masingmasing perlakuan. Rerata dan standar deviasi dihitung untuk setiap ciri-ciri/sifat untuk masing-masing perlakuan.

\subsection{Analisis Vitelogenin Hemolimfa dengan SDS-PAGE}

Analisis vitelogenin hemolimfa di- 
lakukan dengan Sodium Dodecyl Sulfate Polyacrylamide Gel Electroforesis (SDSPAGE; Bio-Rad), yaitu analisis jenis protein berdasarkan berat molekul. Prosedur analisis yang dilakukan dengan memodifikasi metode Nurilmala and Ochiai (2016). Persiapan SDS-PAGE menggunakan $12,5 \%$ gel pemisah dan 3\% gel penahan. Volume sampel yang dianalisis sebanyak $10 \mu \mathrm{L}$ dan marker $(250 \mathrm{KDa})$ sebanyak $3 \mu \mathrm{L}$. SDSPAGE dijalankan pada program 170 Volt, 13 mA selama 2,5 jam.

\section{HASIL DAN PEMBAHASAN}

\subsection{Hasil}

\subsubsection{Analisis Konsentrasi 17 $\beta$-estradiol Hemolimfa Gonggong}

Konsentrasi $17 \beta$-estradiol hemolimfa gonggong sebelum dan sesudah penyuntikan ditampilkan pada Gambar 2.

Kenaikan konsentrasi 17ß-estradiol hemolimfa terjadi pada semua perlakuan pada hari ke-4 pascasuntik. Konsentrasi $17 \beta-$ estradiol pada semua perlakuan mengalami penurunan pada hari ke-10 dan naik kembali sampai hari ke-16. Setelah itu perlakuan suntikan larutan etanol absolut dan minyak jagung naik sampai pada hari ke-30, sedangkan perlakuan lainnya mengalami sedikit penurunan.

\subsubsection{Analisis Pertumbuhan Bobot Gonad dan GSI Gonggong.}

Hasil pengukuran rata-rata bobot tubuh lunak, bobot gonad dan nilai GSI gonggong ditampilkan pada Tabel 2. Bobot gonad, bobot tubuh lunak dan GSI gonggong di akhir perlakuan, setelah pemeliharaan 30 hari pada semua perlakuan mengalami kenaikan dibanding di awal, kecuali nilai GSI perlakuan tanpa suntikan (P1). Perlakuan suntikan larutan stok $17 \beta$-estradiol (P3) memiliki nilai lebih tinggi pada pertumbuhan bobot gonad dan bobot tubuh lunak gonggong. Nilai GSI antar perlakuan tidak berbeda nyata, namun perlakuan P3 memiliki nilai lebih tinggi dibanding perlakuan lain.

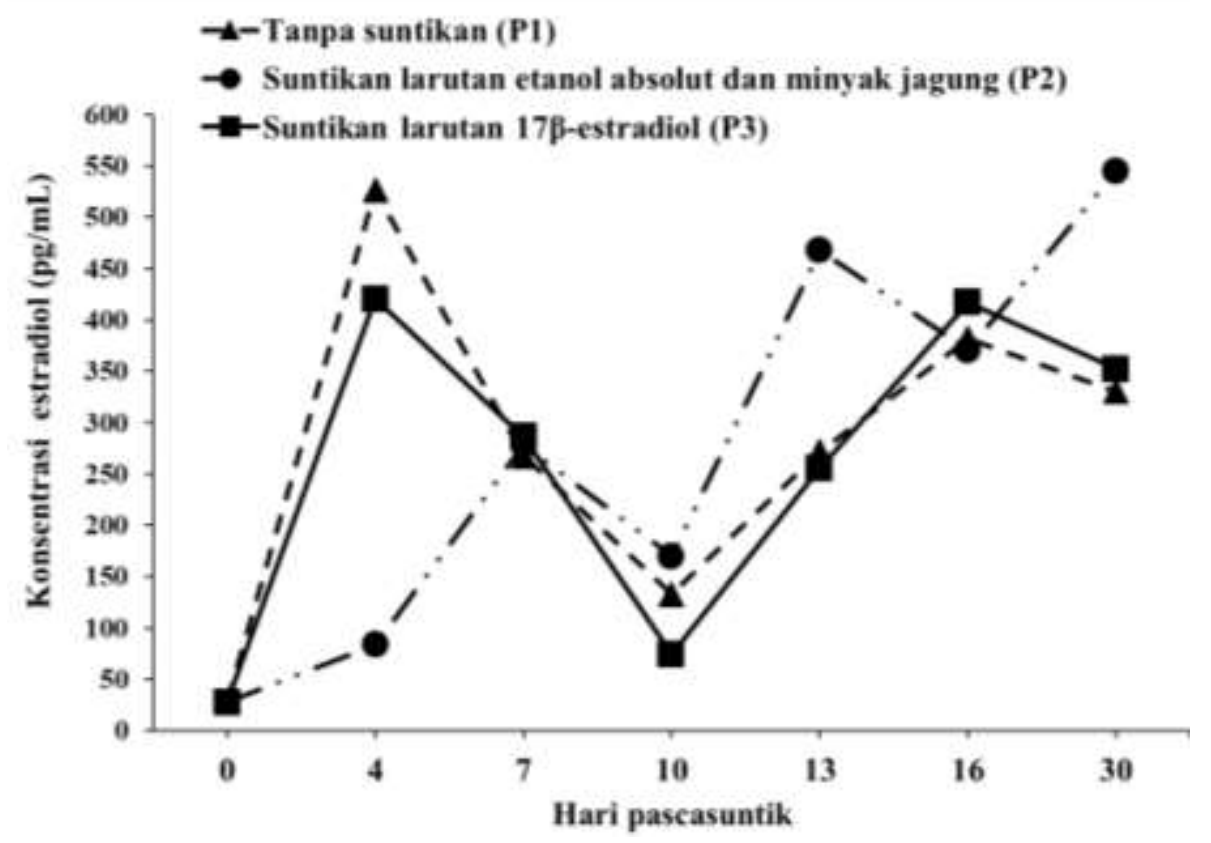

Gambar 2. Rata-rata konsentrasi $17 \beta$-estradiol hemolimfa sebelum dan sesudah diberi suntikan hormon. $\mathrm{P} 1=$ tanpa suntikan; $\mathrm{P} 2=$ suntikan $30 \mu \mathrm{L} / \mathrm{ekor}$ larutan etanol absolut dan minyak jagung; P3= suntikan $30 \mu \mathrm{L}$ /ekor larutan stok $17 \beta$-estradiol. 


\subsubsection{Histologi Gonad dan Diameter Oosit}

Hasil pengamatan histologi gonad siput gonggong 30 hari pascasuntik hormon ditampilkan pada Gambar 3. Parenkima gonad pada ketiga perlakuan dan gonad sebelum perlakuan tampak didominasi oleh kelenjar pencernaan pada bagian tengah (tanda panah biru), sedangkan folikel-folikel oosit hanya pada bagian tepi (tanda panah kuning). Jumlah oosit yang teramati pada perlakuan suntikan larutan 17 $\beta$-estradiol (P3) dan tanpa suntikan (P21) sebanyak 100 oosit, lebih banyak dibanding perlakuan P2 (89 oosit) dan gonad awal (26 oosit). Rerata ukuran diameter oosit yang teramati juga lebih besar pada perlakuan P3 dibanding P1, P2 dan gonad awal. Analisis sebaran diameter oosit gonggong pada hari ke-30 pascasuntikan ditampilkan pada Gambar 4.

Setelah 30 hari pemeliharaan, ukuran rata-rata diameter oosit gonad perlakuan suntikan larutan 17 $\beta$-estradiol (P3) berbeda nyata $(\mathrm{P}<0,05)$ dibanding perlakuan $\mathrm{P} 1$ dan P2. Gonggong pada perlakuan P3 memiliki lebih banyak telur yang berukuran besar.

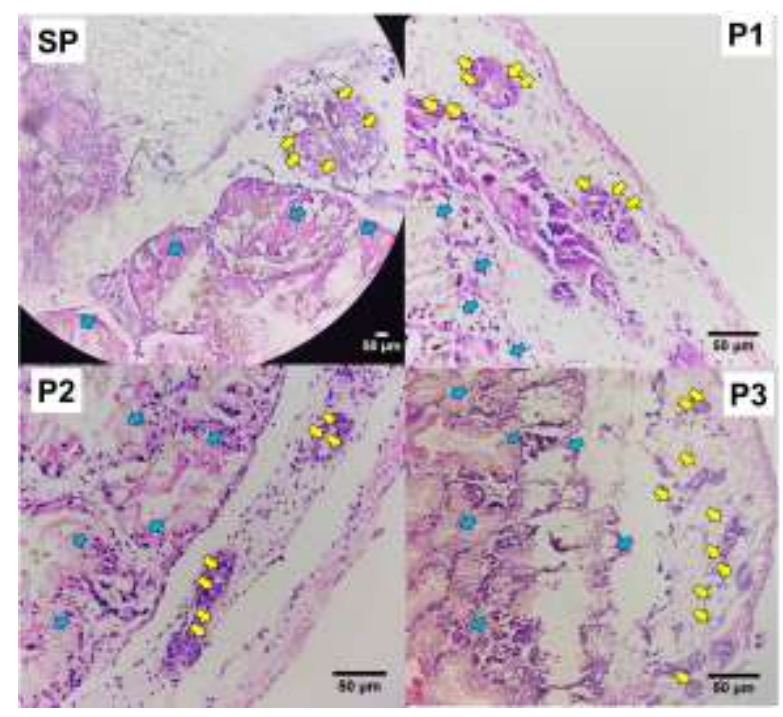

Gambar 3. Histologi gonad gonggong betina sebelum, dan pascasuntikan setelah pemeliharaan 30 hari, masing-masing: sebelum perlakuan (SP), tanpa suntikan (P1), suntikan $30 \mu$ L/ekor larutan minyak jagung dan etanol absolut (P2), dan suntikan $30 \mu$ L/ekor larutan 17 $\beta$-estradiol (P3). Tanda panah kuning menunjukkan oosit, tanda panah biru menunjukkan kelenjar pencernaan. Pewarnaan HE dan perbesaran $40 \times 10$.

Setelah hari kesepuluh, kondisi organ dan fisiologi gonggong normal kembali sehingga kadar $17 \beta$-estradiol hemolimfa naik kembali menuju pematangan gonad. Kadar $17 \beta$-estradiol hemolimfa yang bertahan tinggi sampai hari ke tiga puluh pemeliharaan berpengaruh positif terhadap perkembangan gonad, GSI, dan pertumbuhan gonggong. Berdasarkan pemeriksaan histologi gonad terbukti bahwa ukuran rerata oosit pada perlakuan suntikan larutan 17 $\beta$ estradiol (P3) lebih tinggi dibanding perlakuan P1, P2 dan gonad awal sebelum perlakuan (Gambar 3). Pemberian suntikan larutan 17 $\beta$-estradiol (P3) berperan dalam vitelogenesis yang ditunjukkan oleh adanya peningkatan kadar vitelogenin (Gambar 5).

Menurut Okumura et al. (2004) pada udang, kadar vitelogenin meningkat selama akumulasi kuning telur dan secara signifikan berkorelasi dengan GSI. Meskipun nilai GSI antar perlakuan tidak berbeda nyata, namun pada perlakuan suntikan larutan $17 \beta$-estradiol (P3) nilainya lebih tinggi daripada perlakuan P1 dan P2 (Tabel 2). Hal ini mengindikasikan adanya peran pemberian $17 \beta$ estradiol pada perkembangan gonad gonggong.

Sintesis $17 \beta$-estradiol dalam tubuh gonggong belum diketahui secara pasti sebagaimana halnya dengan kerang (Yan et al., 2011) dan udang (Tarsim et al., 2007). Namun pada bivalvia dan avertebrata lain, sintesis dan metabolisme hormon dan jalur pensinyalannya cukup banyak dipelajari. Hormon estrogen mungkin merupakan promoter primer untuk vitelogenin pada moluska (Yan et al., 2011). Kadar 17 $\beta$ estradiol teridentifikasi baik dalam ovarium 
maupun testis bivalvia laut, tiram peran dalam perkembangan gamet Crassostrea gigas, dan kerang Patinopecten (Matsumoto et al., 1997, McClelland-Green, yessoensis. Kadar 17ß-estradiol dalam ovarium secara konsisten lebih tinggi dari estriol dan meningkat dengan pematangan seksual, sehingga hal ini membuktikan bahwa 17ß-estradiol berperan dalam reproduksi tiram dan kerang, dan dapat disintesis dalam gonad serta diduga memiliki 2008). Adanya berbagai bukti peran penting hormon dalam kontrol reproduksi namun belum ada satu moluska sebagai model umum. Masih sedikit pula yang diketahui tentang tingkah laku dan kontrol hormonal reproduksi pada prosobrancia.

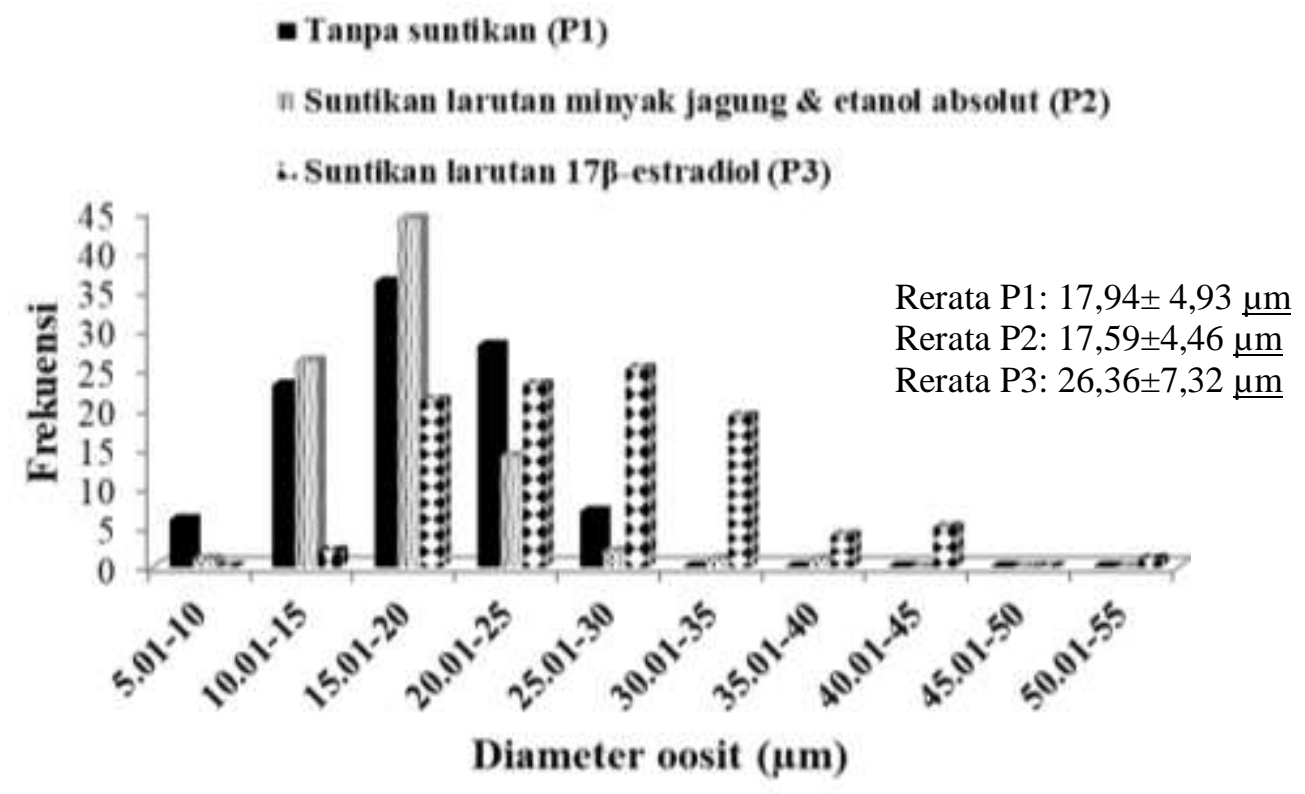

Gambar 4. Frekuensi dan interval ukuran diameter gonad perlakuan suntikan 17ß-estradiol setelah pemeliharaan 30 hari.

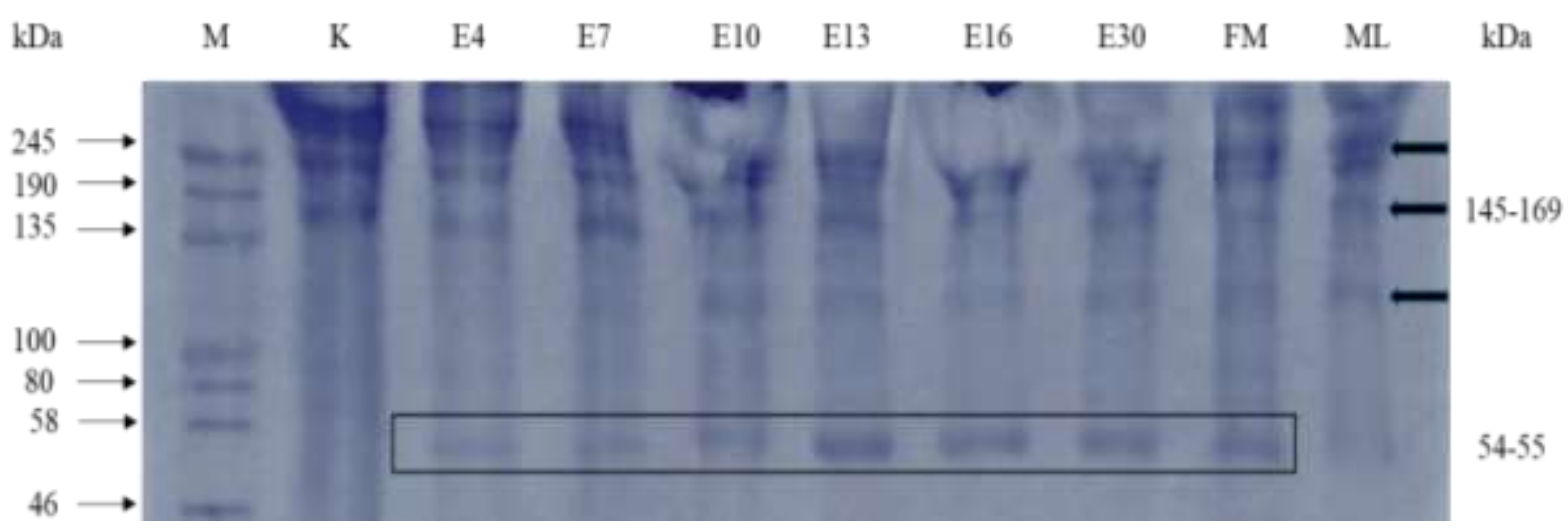

Gambar 5. Protein hemolimfa gonggong: $M=$ marker, $K=$ hemolimfa tanpa suntik, E4-E30= hemolimfa suntikan campuran $17 \beta$-estradiol, minyak jagung dan etanol absolut yang disampling pada hari ke-4, 7, 10, 13, 16, dan 30; $\mathrm{ML}=$ hemolimfa jantan matang gonad, FM= hemolimfa betina matang gonad. 
Tabel 2. Pertumbuhan bobot gonad dan GSI gonggong setelah 30 hari pascasuntik.

\begin{tabular}{|c|c|c|c|}
\hline Perlakuan & Bobot tubuh lunak (g) & Bobot gonad $(\mathrm{g})$ & GSI \\
\hline Tanpa suntikan (P1) & $4,18 \pm 0,77^{b}$ & $0,76 \pm 0,12^{\mathrm{bc}}$ & $18,09 \pm 0,15^{\mathrm{a}}$ \\
\hline $\begin{array}{l}\text { Suntikan } 30 \mu \mathrm{L} / \text { ekor larutan } \\
\text { minyak jagung dan etanol } \\
\text { absolut (P2) }\end{array}$ & $3,57 \pm 0,77^{a b}$ & $0,71 \pm 0,19^{b}$ & $19,90 \pm 1,96^{\mathrm{a}}$ \\
\hline $\begin{array}{l}\text { Suntikan } 30 \mu \text { L/ekor larutan } \\
\text { stok } 17 \beta \text {-estradiol (P3) }\end{array}$ & $4,49 \pm 0,84^{b}$ & $0,99 \pm 0,10^{\mathrm{c}}$ & $22,47 \pm 3,91^{a}$ \\
\hline Bobot awal & $2,49 \pm 0,88^{\mathrm{a}}$ & $0,46 \pm 0,18^{a}$ & $18,81 \pm 4,02^{\mathrm{a}}$ \\
\hline
\end{tabular}

*Huruf yang berbeda menandakan perbedaan signifikan antar perlakuan $(\alpha=0.05), n=3$.

Fluktuasi konsentrasi $17 \beta$-estradiol hemolimfa gonggong selama pemeliharaan diduga karena keragaman sampel hemolimfa uji. Variasi konsentrasi estradiol pada moluska berkolerasi dengan siklus reproduksi, variasi spesies dan status perkembangan gonadnya (Liu et al., 2014; Yan et al., 2011). Fluktuasi kadar 17ßestradiol terkait siklus reproduksi moluska mengesankan bahwa $17 \beta$-estradiol dapat berfungsi sebagai modulator endogen dari siklus reproduksi. Sebagai contoh, konsentrasi 17 $\beta$-estradiol dalam gurita Octopus vulgaris meningkat pada awal vitelogenesis (Cosmo et al., 2001).

Nilai rata-rata bobot tubuh lunak, bobot gonad dan GSI gonggong pada perlakuan suntikan larutan 17 $\beta$-estradiol (P3) lebih tinggi dari perlakuan P1 dan P2 mengindikasikan bahwa pemberian suntikan larutan 17 $\beta$-estradiol dapat menginduksi perkembangan gonad dan pertumbuhan gonggong. Hasil uji statistik Kruskal Wallis $(\mathrm{P}<0,05)$ memperkuat bahwa pemberian suntikan $17 \beta$-estradiol berpengaruh terhadap perkembangan oosit gonad. Hasil tersebut didukung oleh hasil dari Wang and Kroll (2004) yang memberikan suntikan $17 \beta$ estradiol pada kerang Placopecten magellanicus dan terbukti mampu meningkatkan pertumbuhan oosit, serta Kruatrachue et al. (1996) pada siput bekicot (Achatina fulica) yang meningkatkan jumlah oosit ovotestis. Korelasi positif antara 17ßestradiol dengan diameter rata-rata oosit menunjukkan bahwa estradiol terlibat erat dalam oogenesis dan vitelogenesis (Liu et al., 2014). Paparan estradiol terhadap gonad akan merangsang vitelogenesis pada oosit dan memberikan respon perkembangan yang lebih tinggi. Sebaliknya pemakaian minyak jagung yang relatif kurang efektif sebagaimana hasil pada Tabel 2, menurut Delgado and Glazer (2008) sebaiknya diganti dengan dimetil sulfoksida (DMSO). DMSO adalah suatu senyawa organosulfur dengan rumus kimia $\left(\mathrm{CH}_{3}\right)_{2} \mathrm{SO}$, cairan tidak berwarna ini adalah pelarut aprotik polar penting yang larut baik dalam senyawa polar dan nonpolar serta larut pula dalam berbagai pelarut organik seperti air. Larutan $17 \beta$-estradiol dalam DMSO terbukti efektif diaplikasikan pada siput ratu (Strombus gigas).

Berat molekul vitelogenin gastropoda memiliki nilai yang beragam. Fosfoprotein utama dalam crude egg yolk (CEY) siput ratu Strombus gigas memiliki berat molekul 98 kDa (Denslow and Kroll, 2008). Vitelogenin udang Pandalus hypsinotus memiliki berat molekul 290-700 kDa. Kadar vitelogenin hemolimfa udang tersebut rendah sebelum akumulasi kuning telur, dan menjadi jauh lebih tinggi selama akumulasi kuning telur. Kadar vitelogenin secara signifikan berkorelasi dengan GSI selama akumulasi kuning telur. Pada krustasea, vitelogenin disintesis dalam hepatopankreas atau ovarium. Protein tersebut diangkut oleh hemolimfa menuju oosit. Beberapa penelitian 
menunjukkan bahwa kadar vitelogenin hemolimfa berubah dalam kaitannya dengan perkembangan ovarium pada spesies krustasea (Okumura et al., 2004).

Berdasarkan hasil eksperimen di atas diperlukan penelitian lanjutan tentang pengaruh suntikan larutan 17 $\beta$-estradiol terhadap perkembangan gonad gonggong dalam waktu yang lebih lama dan variasi dosis yang lebih lebar, serta dilakukan uji koaglutinasi untuk deteksi vitelogenin yang telah diperoleh dari proses SDS-PAGE.

\section{KESIMPULAN}

Pemberian suntikan larutan 17 $\beta$ estradiol dapat meningkatkan ukuran diameter oosit gonggong perlakuan. Nilai bobot gonad dan bobot tubuh lunak gonggong perlakuan suntikan larutan $17 \beta$ estradiol (P3) lebih besar dibanding perlakuan P1, P2 dan bobot awal gonggong. Nilai GSI antar perlakuan tidak berbeda nyata, namun nilainya pada perlakuan P3 lebih tinggi dibanding perlakuan lain. Hemolimfa gonggong memiliki beberapa jenis protein dengan pita berat molekul bervariasi. Protein dengan berat molekul 54$55 \mathrm{kDa}$ diprediksi sebagai vitelogenin gonggong.

\section{UCAPAN TERIMA KASIH}

Penelitian ini didanai oleh Direktorat Riset Pengabdian Masyarakat-Kemenristekdikti RI dengan skim Penelitian Disertasi Doktor (PDD) dengan nomor kontrak 064/SP2H/LT/DRPM/2018. Terima kasih disampaikan kepada Direktur DRPM Kemenristekdikti, Rektor UMRAH, Kepala LP3M UMRAH, Dekan FIKP UMRAH, Kepala Marine Biology Laboratory FIKPUMRAH atas bantuan fasilitas dan dukungannya dalam penelitian ini, Kepala Laboratorium Biologi Molekuler Hasil Perairan FPIK-IPB Dr. Mala Nurilmala, Kepala Laboratorium Kesehatan Ikan FPIKIPB, Kepala Laboratorium Hormon URR
FKH-IPB, Kepala Laboratorium Histopatologi FKH-IPB, Kepala Laboratorium PSSP-IPB, Drh. Dedi Setiadi, Drh. Silvia, Ranta, Zulpikar, Hamzah, Rohayati, Siti Nurbaya dan sahabat baikku Budi Primulia, Hasan Nasrullah, Agus Muslim serta semua pihak yang telah banyak membantu Penulis.

\section{DAFTAR PUSTAKA}

Barber, B.J. and N.J Blake. 1991. Reproductive Physiology. In: Shumway S.E. (ed.). Scallops: Biology, Ecology and Aquaculture. Elsevier Press. New York. 377-428 pp.

Cob, Z.C., A. Arshad, M.A Ghaffar, and J.S Bujang. 2008a. Sexual maturity and sex determination in Strombus canarium. J. Biological Science, 8(3): 616-621. https://doi.org/10.3923/jbs.2008.616. 621

Cob, Z.C., A. Arshad, H.M. Idris, J.S. Bujang, and M.A. Ghaffar. 2008b. Sexual polymorphism in a population of Strombus canarium Linnaeus, 1758 (Mollusca: Gastropoda) at Merambong Shoal, Malaysia. Zoological Studies, 47(3): 318-325.

Cosmo, A., C. di Cristo, and M. Paolucci. 2001. Sex steroid hormone fluctuations and morphological changes of the reproductive system of the female of Octopus vulgaris throughout the annual cycle. $J$. experimental zoology, 289: 33-47. https://doi.org/10.1002/1097010X(20010101/31)289:1<33::AIDJEZ4>3.0.CO;2-A

Delgado, G. and R. Glazer. 2008. Collections of conch tissue, water, and sediment. In: Glazer R. (ed). Anthropogenic effects on queen conch reproductive development in South Florida. A Final Report. Ocean Springs Press. Florida. 3-5 pp. 
Denslow, N. and K. Kroll. 2008. Protein biomarkers. In: Glazer R. (ed). Anthropogenic effects on queen conch reproductive development in South Florida. A Final Report. Ocean Springs Press. Florida. 6-15 pp.

Di Cristo, C., Paolucci M., and A. Di Cosmo. 2008. Progesterone affects vitellogenesis in Octopus vulgaris, $J$. Zoology, 1: 29-36. http://doi.org/10.2174/187433660080 1010029

Di Prisco, C.L., F.D. Fulgheri, and M. Tomasucci. 1973. Identification and biosynthesis of steroids in the marine mollusk Aplysia depilans. J. Comp Biochem Physiol, 45(B): 303-310. https://doi.org/10.1016/03050491(73)90065-5

Keay, J., J.T. Bridgham, and J.W. Thornton. 2006. The Octopus vulgaris estrogen receptor is a constitutive transcriptional activator: evolutionary and functional implications. $J$. Endocrinology, 147(8): 3861-3869. https://doi.org/10.1210/en.2006-0363

Kruatrachue, M., K. Songmuang., E.S. Upatham, P. Sretarugsa, and J. Chavadej. 1996. Effects of vertebarate hormones on the reproductive system of Achatina fulica (Gastropoda: Stylommatophora). J. Sci.Soc. Thailand, 22: 249-265.

Li, Q., M. Osada, T. Suzuki and K. Mori. 1998. Changes in vitellin during oogenesis and effect of estradiol on vitellogenesis in the Pacific oyster Crassostrea gigas. Invert. Reprod. Dev, 33: 87-93. https://doi.org/10.1080/07924259.199 8.9652345

Liu, J., Z. Zhang, L. Zhang, X. Liu, D. Yang, and X. Ma. 2014. Variations of estradiol-17 $\beta$ and testosterone levels correlated with gametogenesis in the gonad of Zhikong scallop (Chlamys farreri) during annual reproductive cycle. J. Zool, 92: 195-204.

https://doi.org/10.1139/cjz-2013-0202

Lu, M., T. Horiguchi, H. Shiraishi, Y. Shibata, M. Abo, A. Okubo, and Yamazaki S. 2001. Discrepancy of analytical values of steroid hormones in marine gastropods between GC/MS and ELISA. Analytical Sciences, 17: 1619-1622.

https://doi.org/10.14891/analscisp.17i cas. 0.11619 .0

Marentette, J.R. and L.D Corkum. 2008. Does the reproductive status of male round gobies (Neogobius melanostomus) influence their response to conspecific odors? $J$. Environmental Biology of Fishes, 81: 447-455.

http://doi.org/10.1007/s10641-0079240-7

Matsumoto, T., M. Osada, Y. Osawa, and K. Mori. 1997. Gonadal estrogen profile and immunohistochemical localization of steroidogenic enzymes in the oyster and scallop during sexual maturation. J. Comp Biochem Physiol, 118B: 811-817. https://doi.org/10.1016/S03050491(97)00233-2

McClellan-Green. 2008. Analysis of queen conch neuropeptide expression. In: Glazer R. $(e d)$. Anthropogenic effects on queen conch reproductive development in South Florida. A Final Report. Ocean Springs Press. Florida. 71-76 pp.

Muzahar and A.A. Hakim. 2018. Spawning and development of dog conch Strombus sp. larvae in the laboratory. J. Ilmu dan Teknologi Kelautan Tropis, 10(1): 209-216. http://dx.doi.org/10.29244/jitkt.v10i1. 18607

Muzahar dan L. Viruly. 2014. Karakterisasi kimia. sensori dan laju pemijahan gonggong (Strombus sp.) sebagai 
ikon Kepulauan Riau. J. Dinamika Maritim, 3(2): 20-29.

Nurilmala, M., and Y. Ochiai. 2016. Molecular characterization of southern bluefin tuna myoglobin (Thunnus maccoyii). J. Fish Physiology and Biochemistry, 42(5): 1407-1416. https://doi.org/10.1007/s10695-0160228-0

Okumura, T., K. Yoshida, and H. Nikaido. 2004. Ovarian development and hemolymph vitelogenin levels in laboratory-maintained protandric shrimp (Pandalus hypsinotus): Measurement by a Newly Developed Time-resolved Fluoroimmunoassay (TR-FIA). J. Zoological Science, 21(10): 1037-1047. https://doi.org/10.2108/zsj.21.1037

Osada, M., T. Takamura, H. Sato and K. Mori. 2003. Vitellogenin synthesis in the ovary of scallop Patinopecten yessoensis: control by estradiol-17 $\beta$ and the central nervous system. $J$. Exp Zool, 299A: 172-179. http://doi.org/10.1002/jez.a.10276.

Ranabir, S. and K. Reetu. 2011. Stress and hormones. Indian J. Endocrinol Metab, 15(1): 18-22. http://doi.org/10.4103/22308210.77573

Sánchez, F.C., M.E. Díaz, I.M. Morales, and D.A. Aranda. 2016. Formulated feed for Strombus pugilis (Mollusca, Gastropoda) allowed effective gonad maturity. J. Aquaculture Research \& Development, 7(10): 1-8. https://doi.org/10.4172/21559546.1000453
Sathyan, N.R., Philip, E.R. Chaithanya, and R.R.A. Kumar. 2012. Identification and molecular characterization of molluskin, a histone-H2A-derived antimicrobial peptide from molluscs. J. Molecular Biology, 1-6. https://doi.org/10.5402/2012/219656.

Setiadi, D.R., I. Supriatna, dan M. Agil. 2014. Validasi kit enzyme-linked immunosorbent assay komersial untuk analisis hormon estradiol dan progesteron darah kambing kacang. $J$. Veteriner, 15(4): 446-453.

Tarsim, MJr. Zairin, dan E. Riani. 2007. Rangsangan perkembangan ovari udang putih, (Litopenaeus vannamei) dengan penyuntikan estradiol-17 $\beta$. $J$. Akuakultur Indonesia, 6(1): 17-25. https://doi.org/10.15578/jra.2.3.2007. 349-358

Wang, C., and R.P. Croll. 2004. Effects of sex steroids on gonadal development and gender determination in the sea scallop Placopecten magellanicus. J. Aquaculture, 238: 483-498. https://doi.org/10.1016/j.aquaculture. 2004.05.024

Yan, H., Q. Li, W. Liu, Q. Ke, R. Yu, and L. Kong. 2011. Seasonal changes of oestradiol-17 $\beta$ and testosterone concentrations in the gonad of the razor clam (Sinonovacula constricta, Lamarck, 1818). J. Molluscan Studies, 0: 1-7. https://doi.org/10.1093/mollus/eyq04 5

Received : 14 May 2019

Reviewed : 03 July 2019

Accepted : 15 September 2019 
